\title{
Effective Management Workshop and Creative Work for Improving Students Practice Skills
}

\author{
Tetty Setiawaty \\ Department of Technical and Vocational Education \\ Faculty Teacher Training and Education Science, Nusa Cendana University \\ J1. Adisucipto Penfui - Kupang 85000 Indonesia \\ tettysetiawaty@gmail.com
}

\begin{abstract}
This research's purpose is to describe effective workshop management and workshop creative work in Vocational School to improve the enhancement student practical skill. Research method applies case study qualitative, data collection technique using: in depth interview, participant observation and documentations. The subjects of this research are schools indicators and industrial partnership. The objects of the research are the application of effective workshop management and workshop creative work. Result of the research reveals that workshop management is lead by Vice Principal of Practical Curriculum and the workshop leader apply effective management into workshop indicators. The effective management conducts these terms, such as planning, organizing, acting, coordinating and controlling. Creative work done separating theoretical and practical curriculum. The responsibilities of the Vice Principle of Curriculum are creating productive curriculum based on work market, considering quality target, applying learning Method PBL and controlling quality of the student's work product.
\end{abstract}

Index Terms - effective management workshop, creative work, skill practice, project-based learning.

\section{Introduction}

Quality of Indonesia Education is considered in a low level. Several indicators consider the problems are (1) graduate of a High school and University has not been employed already because of the minimum competences they have [1]; (2) result of Human Development Index (HDI) 2013, Indonesia is on 121st level from 186 countries and 8 territorial countries so Indonesia is on Medium Human Development [2]-[3]; (3) based on UNDP monitor, Indonesia reaches score 0, 629 and change into 0,009 , consist of employee, health and education [4]; (4) result of Program for International Student Assessment (PISA) 2012, shows that the ability of Indonesian children at mathematics, science and reading shows in 64 th from 65 th countries taking a part in the test [5]- [6].

Another problem are the amount of unemployed people in February 2013 reaches 7,2 Million. Despite this problem is deeply concern, opened unemployed people level Indonesia in February 2013 reaches 5,92\%, experience decreasing compared TPT in August 2012 shows 6,14\% and TPT February 2012 as 6,32\%. Based on
TPT, people at the age of 15 above, according to the highest education who is graduated in 2012/2013, Vocational High School (SMK) experience decreasing into 7,68 (February 2013) from 9,51 in February 2012 and $10 \%$ in February 2011 from all Indonesian worker. While work field structure in Indonesia does not change until February 2013.in which industrial sector and construction still becomes the biggest supporting segment after farming and trading [7]. The data above shows that the numbers of those who graduate from Vocational High School are not accepted in work field totally. Difficult things for getting a job is caused by the different among the education program given, work field needs and arranging of Vocational High School pattern based on quantity without putting a weight on the quality of the graduate [8] - [9]. These symptoms must be reorganized immediately in order to get qualified and competence Vocational High School graduates.

Globalization era signed by fast moving of information technology development, it causes the high competition of human resource, beside giving a chance and challenge it also give a treatment for the unemployed people who have not been already yet, because of the competition which comes from several countries. Indonesia as a developed Country must be capable to overwhelm the free market that full of challenge and competition. For anticipating this era, Indonesian human resource is accused to have high skill and competitive advantage in order to compete in fighting for job field. Tough graduate, excellent, high-tech, and capable in competition is really need in facing to this globalization era.

To overwhelm the problems above, Vocational High School is accused to apply cultural reformation management by changing the old habit which is not suitable with a new working world. The importance of effective management in Vocational High School because effective management is able to give a better education either for neither student nor the teacher so that it can make a school become more qualified [10]- [13].

Workshop management is really need value that orient on education quality, productivity, accuracy, speed, the satisfaction of stakeholder and also the development of science and technology. For producing effective workshop management, it needs creative workshop that improves student practical skill. Based on the explanation above, it can be concluded that effective workshop management and effectiveness work of workshop are able to improve the efficiency of education resources empowerment needed so that a school is capable in improving student practical skill and produce a qualified graduate as good as the working world need.

\section{Method}


This research applies qualitative research and qualitative approach of case study by collecting data and in depth interview, participant observation and documentation [14]. This research is done in PIKA Vocational High School, furniture production skill and Mikael Vocational High School based on mechanical engineering skill as competence. The reason of this research done in these schools, both of they are excellent Vocational High School with specific character, unique, and it is capable in producing graduate who is ready to work, if it is compared with other Vocational High School.

Subjects of the research are the principal, Vice Principal of Practical Curriculum, teacher, instructor, students, alumnus, industry partnership and documentation data. All the school personal become research sample except student and industry partnership that is taken by purposive sampling technique. The objects of the research are workshop management and workshop creativity. Research instruments used is human instruments. Qualitative data analysis technique using interactive model from [15], using repetitive data analysis from data collection, conclusion drawing/ verification). The data from the research result that is submitted, it is analyzed continually during the research process until getting the valid data, then doing some data explanation, drawing conclusion from the research result done.

\section{The Result of the Research}

\section{a. Effective workshop management.}

The result of research shows that PIKA and Mikael Vocational School run the management based on 11 indicators effectively. Effective management done by planning, organizing, acting, coordinating and controlling all school indicators. Practical learning management is the central point from workshop management, because the students are centered learning of Vocational School is on Practical activity in workshop. The existence of workshop as the place for training the student knowledge and skill, supported by workshop indicator that replace on its own function and connected each other with the succeed of Vocational education [16]-[17]. Effective workshop management can been seen based on this chart.

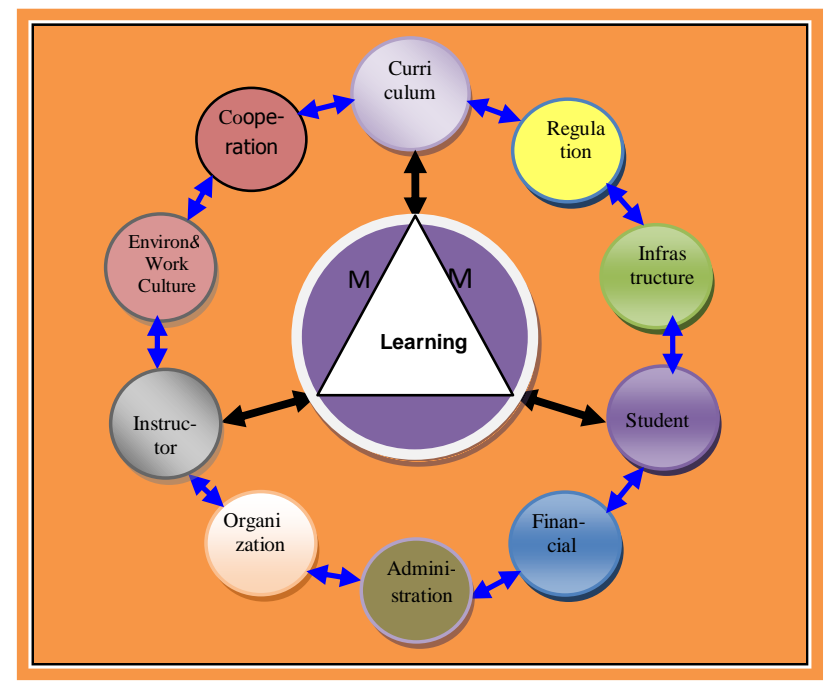

Fig-1. School Indicator Management

1) Learning Management: PIKA Vocational High School applies 4 years for study, the first until the third year, student studies at school and continued by learning process in joining industry partnership in foreign furniture company which has cooperated with PIKA. Mikael applies 3 years study, both theory and practice are studied at school. Industry partnership of Mikael Vocational High School done in ATMI by the $3^{\text {rd }}$ year student for 2 months based on regular practical schedule. Practical study divided into two terms, mechanical practice and technical drawing. PIKA Vocational school applied 5 days study, in which Monday to Friday, Monday to Thursday (06.55-15.30) and Friday (06.55-16.00), it is used for 1 semester. Theoretical study in Mikael Vocational School 6 working hours (Monday to Saturday), start from 7.0014.15 (Monday-Thursday), 07.00-14.00 (Friday) and 07.0012.00 (Saturday). Theoretical and practical study apply 11 kinds of weekly subjects in odd semester and 14 kinds of even semester. Student practice based on shift split, morning shift 06.55-12.00) and afternoon shift $(12.55-18.00)$ for $1^{\text {st }}$ year student. The $2^{\text {nd }}$ and $3^{\text {rd }}$ year join morning shift $06.55-14.45$ and evening shift 14.25-22.00.

2) Workshop Organization Management: Workshop organization is lead by the head of workshop. The head of workshop is responsible for managing practical study, instructor and student. Workshop organization management in PIKA Vocational High School and Mikael Vocational High School apply standard ISO 9001:2008. That standard accuses workshop to put the weight on demand, hope and willingness of the customer as a priority and often do remedial things continually related to practical study and student production quality. Quality control of practical study process and production quality helped by internal quality control done by instructor and the head of workshop and external QC done by industrial production division neither PIKA nor ATMI.

3) Curriculum management: Curriculum management divides into theoretical curriculum and practical curriculum. Theoretical curriculum lead by vice of principal and practical curriculum lead by Vice Principal IV. Vice Principal IV responsible for practical curriculum management, student practical activity, instructor, practical material and teaching material, managing workshop and practical machinery, trouble shooting for machinery problem, production, managing student and all things related to practical study. Curriculum used is a curriculum orientate on work market so the good produced is suitable for society and industrial company, this condition accuse students works as good as product standard of industrial company work process, industrial company safety working.

4) Teacher Management: The requirement for being an instructor, especially technical drawing for furniture In PIKA, teacher must be graduate of PIKA Vocational High School or Academy of PIKA, for Mikael Vocational High School or ATMI, the requirement for being a teacher in that school is a graduate from both school. Those schools determine requirements for being a teacher, because they have a good discipline at attitude and industrial work culture. Other requirement for practical teacher is having work experience in industrial company for minimum 2 years experience, that experience is really helpful in practical learning process, instructors can apply the experience during the period when working for industrial company to the students, such as product quality knowledge, using production time effectively and efficiently, work discipline and attitude, etc.

5) Student Management: Student management run the things related to student personality counseling and student extracurricular. Student activity doesn't only about managing 
the student's problem but also taking a good care to prestige student. For finding the problem faced by the students, students usually hold class family gathering in once a month in which a home room and several teacher attend. Student management is run by making student activity plan, student counseling, socializing student guide book, and practical guide book, disciplinary student coaching extracurricular activity, religious activity, consulting with parent and case conference if the student break the regulation for medium or serious level and sent the student to Industrial company.

6) Practical Infrastructure management: Practical infrastructure management is handled by vice principal IV and the head of workshop working together with vice principal II (infrastructure division). Vice principal in doing the task is started from material and machinery plan, supplying, purchasing and machinery maintenance during in a study year. In Managing facilities, PIKA Vocational High School cooperates with general division PIKA. While Mikael Vocational High School manages the facility by its self starting from planning, supplying, purchasing until throwing used things.

7) Finance and costing management: Financial and costing management is responsibility of the head of workshop. Planning and costing is grouped into 4 activities in a study year, they are: budgeting, accounting, auditing and evaluating cash flow. Workshop financial data is divided into two parts, they are: debit and credit. Debit comes from student finance, such as: student practice cost from each class, exhibition income, government contribution, society and industrial company contribution, scholarship and etc. Credit is divided into two parts, student competence examination, training and seminar, accidental insurance, etc. Costing is used for salary and over time payment, maintenance and repairing cost of machine, human resource development, invest, saving cost, etc. Controlling workshop finance based on checking financial report, and the discipline in using money, financial operational and financial cash flow.

8) Administration management: Administration activity consists of: data administration (practice curriculum, practice material, examination exercises sheet in a semester, student competence examination exercises, etc), student administration, employee administration, cooperation of Industrial company administration, expedition administration. Administration activities are: (1) grouping things,/goods/file/document and save them according to the classification; (2) preparing a specific place to save them so that it is easier to recognize; (3) giving limitation mark clearly so that it will not be complicated; (4) labeling as an identity to find things easier (when it is needed); and (5) mapping/list of things/goods/file/document, to help people recognize and find them easily.

9) Regulation management: Student counseling discipline during practical lesson based on the regulation ruled in student guide book and work guide in workshop. The purpose of regulation management is to make student discipline working in a workshop. Student who against the regulation or does distortion will be punished according to the fault point. For keeping student security during practical lesson, student is instructed to obey all regulation, such as time discipline. Student who against the regulation will be punished according to the fault point. The school will collect the student's fault point for a semester and it will be accumulated in the end of semester. Mikael will give punishment all at once for the fault done by student. Compensation in workshop is finish the unfinished work or working for production.

10) Environment and working culture: Environment and working culture completes environmental cleanliness equipment and working culture, create environment that support learning process (safe, clean, comfortable, neat, in order, beautiful and green) consistently, PIKA Vocational High School does 5R (simple, clean, neat, well maintained and diligent ) and Mikael Vocational High School does 2R (simple and clean) during practice activity in a workshop and develop work safety regulation refers to Industrial working safety and do practical learning according to the industrial working culture. School puts all things, goods/ file/ document according to the place and function, so that it can be found easier when it is needed. Clean environment and industrial work culture is capable to improve student and instructor spirit to be better and more productive.

11) Cooperation and partnership management: Marketing hold an important role to introduce a school outside, to the society and industrial company. Marketing ability is really accused to approach industrial company and society. Approaching is done by placement of student in the industrial company. Production approach, production order approach, and a place where student sent for Industry partnership. For improving better cooperation, school marketing always keep the good image of school and apply win-win solution system. Develop and widen cooperation and partnership network done continually, to improve the number of other schools and industrial company who will be partner. Cooperation is done in training, seminar, research, industry partnership and production. To improve cooperation, school invite the society, industrial company and alumnus to take a part in the activity, make a report about the next and previous activity on the website.

\section{b. Workshop creative work}

1) Vice Principal for Practical Curriculum: School policy separate practical curriculum and theory curriculum really helpful to manage practical learning, because job of vice principal IV become clearer and more focus. Vice principal has task, responsibility and obligation in handling practical activity. Practical activity done are: first, workshop management, consist of dividing practice material for each class, checking student practical equipment, creating lesson plan, planning practice method and equipment, conducting practical learning, making machine placement layout, making organigram, conducting the agreement with production division, and mapping production process. Second, instructor management, consists of: making job description each division, appraising students work, appraising instructor work performance, and recap mark and inform both student appraisal and instructor appraisal. Third, student management, do the activity: training attitude, teaching student discipline value, honesty and hard working during practical learning process, teach student practical skill.

2) Curriculums: Practical curriculum used is productive curriculum oriented on work market. School will be much specific because it only has 1 skill competence and apply curriculum plus by combining government curriculum and industrial company curriculum. The application of curriculum plus is able to produce high learning quality seriously indeed, 
effective time learning. For improving practical learning quality, school develop and remedy curriculum together with industrial company continually, in order to produce graduate who is ready to work. Industrial company as the user of graduate always control curriculum as good as school applied, it can be seen from the alumni who work for the company. Result of curriculum plus applied in the school is able to produce graduate who has a good quality in job field and become good prestige in a work place.

3) Considering quality target: School applies ISO 9001; 2008 in managing all division in workshop. For improving learning quality, Vice of Principal decides quality target on Workshop activity, such as, quality target for practical learning, instructor and students. Quality target is made every year, by adding or changing quality target the previous year. Considering quality target based on yearly school work plan. For looking up on the achievement of quality target, vice principal IV work together with the head of workshop, instructor and WMM by coordinating ad evaluating quality target achievement. Vice principal IV works together with instructors and students to reach the achievement workshop quality target decide Project in the early study year.

4) Project Based Learning: Practical learning in workshop using Project Based Learning PBL) method in which all the students material are customer's order which come from industrial company and society or producing some goods as stock in the warehouse. Applying PBL method asks the workshop to be active and dynamics in analyzing all income orders, and then they have to draw and arrange it to be student's material. By Applying PBL, the students material will be different each year, because it is fixed with order or updated product.

5) Quality Control $(Q C)$ : QC purpose is controlling the quality of student's production. Controlling quality conducted such as first, controlling product suitability, in order to maintain quality of student's production. School conducts double QC work, QC I is conducted by Instructor and QC II conducted by industrial company, the product which is success both QC process will sent to industrial company while the failed one will sent back to the student to repair. Double QC system is very helpful to maintain quality of students' production for being as good as Industrial Company's order. Second, controlling customer's satisfaction, the result of the customer's satisfaction can be seen on customer's satisfaction questioner given to the students. Third is correction activity in order to find the different what the students do including customers complain. Based on the input data, indifference needed to do is remedy the academics and non academics aspect.

6) Learning evaluation: Learning evaluation is conducted continually, using process evaluation and result evaluation. The assessment of process evaluation is conducted during the students are doing the practical learning and result of evaluation assessment from the result of student practical test. Student's practical learning assessment classified into two parts, objective assessment (70\%) and subjective assessment (30\%). Beside examination in a semester, another examination conducted by this school is student competence test, consist of: technical drawing test for third year student in PIKA and welding competence test for third year student in Mikael, mechanical competence test for third year student in both schools. Especially for PIKA, final assessment is paper examination which is made during industrial partnership work in a year. The paper examination is examined by some people from school and industrial company. Student who is failed must work overtime in a workshop. Practical work overtime is categorized: the incompetence student and student who break the machine or practical equipment.

More clearly, workshop work creativity can been seen based on this chart.

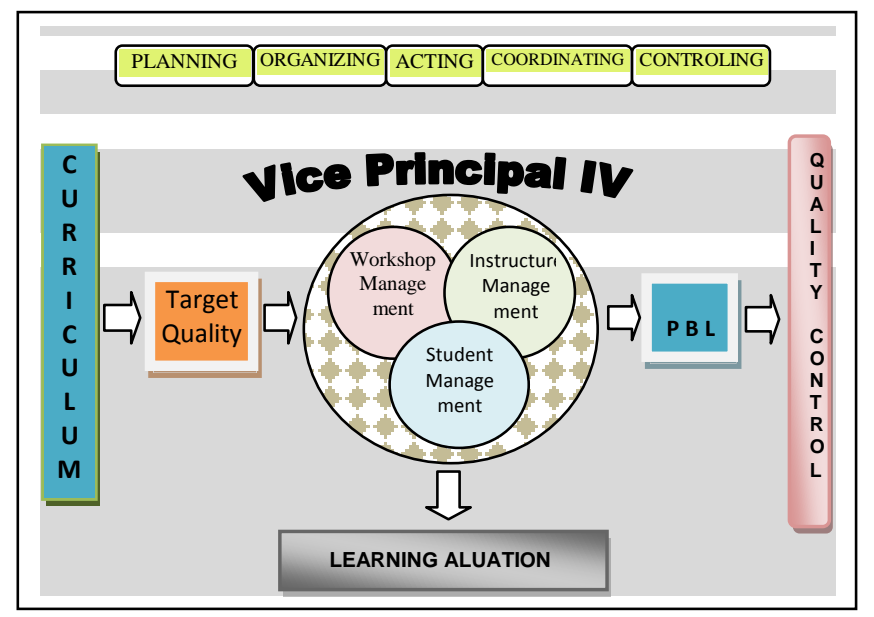

Fig-2. Workshop Creative Work

\section{Conclusion}

Conclusion taken from this research are :

a. PIKA Vocational High School and Mikael Vocational High School conducts management based on 11 workshop indicators effectively. Workshop management conducts activity by planning, organizing, acting, coordinating and controlling. Conducting workshop management effectively make these school become favorite Vocational High School in Indonesia which is able to produce skilful graduates, ready to work and having good prestige at work performance.

b. Workshop creative work conducted by pointing Vice Principal IV who is especially responsible for practical curriculum. The duties of Vice Principal IV are, responsible and having right for managing practical learning curriculum, both instructor and students. Creative work accuses workshop innovate continually based on curriculum and practical material in order to be able in improving student practical skill and workshop work performance.

\section{Acknowledgment}

The authors would like to thank the principal PIKA Vocational High School and Mikael Vocational High School, 
which has research is done, and the Directorate of HigherEducation, Ministry of Education and Culture of the Republic Indonesia, which has provided funding of this research.

\section{References}

[1] Kunandar, "Guru Profesional Implementasi Kurikulum Tingkat Satuan Pendidikan (KTSP) dan Sukses dalam Sertifikasi Guru", Jakarta : Raja Grafindo Persada, pp 1. 2007.

[2] Laksono, Agung. "HDI Indonesia Naik Tiga Peringkat. ( http:// www. satunews.com/read/20034/2013/03/20/html)

[3] UNDP ," Human Development Report 2013", (http://hdr. undp. org/sites /default/files/reports/14/hdr2013_en_complete.pdf). 2014.

[4] UNDP, “ Human Development Index 2013', (http://hdr. undp. org/en /2013-report ). 2014.

[5] OECD, “ PISA 2012 Database”, (http://pisa2012.acer.edu.au/ downloads.php). 2013

[6] Kompas. “ Posisi Indonesia Nyaris Jadi Juru Kunci” Jakarta: Harian Kompas 5 Desember 2013.

[7] BPS, "Statistik Keadaan Ketenagakerjaan Februari 2013". Badan Pusat Statistik No 35/05/Th. XVI, 6 Mei 2013. (http://www.bps. go.id /brs_file/naker_06mei13.pdf.) 2013.

[8] Murniati, A.R. “ Pemberdayaan Sekolah Menengah Kejuruan Melalui Manajemen Stratejik (Studi tentang Penyelenggaraan SMK Negeri untuk Menyiapkan Lulusan yang Sesuai dengan Kebutuhan Pasar Kerja di Banda Aceh Nangroe Aceh Darussalam)", Disertasi. (http://digilib.upi. edu/pasca/ available/etd-1229105-133617). 2014

[9] Sukardi, TH. "Pengembangan Model Bengkel Kerja Praktek Sekolah Menengah Kejurua". Disertasi. Yogyakarya. pp 1. 2008.

[10] Bush, T. \& Coleman, M. "Leadership and Management Development in Education ", SAGE Publication Ltd. pp 12-14, 2008.

[11] Mitchell, J., Chappell, C., et al. " Quality is the Key: Critical Issues in Teaching, Learning and Assessment in Vocational Education and training" Australia Government. (http://www .ncver.edu.au/publications/1710.html). 2006.

[12] Mulcahy, Dianne. “Leadership and Management in Vocational Education and raining: Staying Focussed on Strategy". Volume 1. Australian National Training Authority. (http://www. ncver.edu.au). 2003.

[13] Yuksel-Sahin, Fulya and Hotaman, Davut. " Vocational Guidance Aid in The Orientation to Teaching Profession and Teacher Education". European Journal of Social Sciences. Volume 10, Number 1, (http://www.eurojournals.com). 2009.

[14] Yin, Robert K . Case Study Research: Design and Methods. Sage Publications Ltd. 2006.

[15] Miles, M. \& Huberman, AM. “Analisis Data Kualitatif”. Jakarta: UI Press.pp. 16-17. 2007.

[16] Setiawaty, Tetty, “Improving the Performance Quality of SMK in Central Java", Conference Paper at RMIT University. Melbourne-Australia, pp 3-5, 2008.

[17] Setiawaty,Tetty. Effective Management of Vocational High School. Dissertation. Yogyakarta: Graduate School, Yogyakarta State University, 74-75, 2011. 